\title{
GAMBARAN HEALTH BELIEF MODEL WUS DALAM DETEKSI DINI KANKER LEHER RAHIM MENGGUNAKAN PEMERIKSAAN IVA DIPUSKESMAS BAREGBEG 2021
}

\author{
PICTURE OF HEALTH BELIEF MODEL WUS IN EARLY \\ DETECTION OF CANCER Cervical USING THE EXAMINATION \\ IVA IN PRIMARY BAREGBEG 2021
}

\author{
Siti Rohmah ${ }^{1 *}$, Sandra Tiara Anggraeni ${ }^{2}$ \\ 1,2,3 Universitas Galuh, Indonesia \\ Jalan R.E Martadinata No.150 Ciamis 46213, Indonesia \\ *E-mail corresponding: rohmah.siti.87@gmil.com \\ (Diterima: September 2021; disetujui Oktober 2021; dipublish November 2021)
}

\begin{abstract}
ABSTRAK
Kanker leher rahim merupakan keganasan yang terjalin pada leher rahim merupakan bagian terendah dari rahim yang menonjol ke puncak liang vagina, kanker leher rahim dapat dideteksi dini dengan menggunakan metode pemeriksaan IVA. Masalah yang utama yaitu rendahnya peminat pemeriksaan IVA. Health Belief menjadi penyebab yang mengakibatkan peminat rendah, karena health belief yang kurang. Penelitian ini bertujuan untuk menggambarkan health belief WUS di wilayah kerja PUSKESMAS Baregbeg dalam deteksi dini kanker leher rahim menggunakan metode pemeriksaan IVA. Metode penelitian ini deskriptif. Teknik sampling menggunakan non probality sampling (consecutive sampling) dengan jumlah responden 126 WUS. Hasil penelitian $46(36,5 \%)$ WUS dengan health belief baik, dan $80(63,5 \%)$ dengan health belief kurang. Diharapkan bagi penyelenggara program IVA untuk meningkatkan penyuluhan dan penyebaran informasi terkait adanya program gratis pemeriksaan IVA untuk meningkatkan kesadaran WUS dan meningkatkan kunjungan program skrining deteksi dini kanker leher rahim menggunakan metode pemeriksaan IVA.
\end{abstract}

Kata Kunci: Health Belief Model, IVA, Kanker Leher Rahim, WUS

\begin{abstract}
Cervical cancer is a malignancy that is entwined in the cervix, which is the lowest part of the uterus that protrudes to the top of the vaginal canal. Moreover, cervical cancer can be early detected by using the IVA examination method. Furthermore, the main problem is the low interest in conducting the IVA examination. In addition, Health Belief is recognized as the cause of low interest. In the meantime, this study aims to describe the health beliefs of WUS in the working area of Baregbeg Public health center in early detection of cervical cancer using the IVA examination method. On the other hand, the study carried out a descriptive method. The sampling technique used non-probability sampling (consecutive sampling) with 126 WUS respondents. The results of the study $46(36.5 \%)$ WUS indicated the good awareness of healt beliefs and $80(63.5 \%)$ indicated the unawareness of health beliefs. Regarding the result, it is hoped that the organizers of the IVA program will conduct counseling and inform more information related to the free IVA examination program to increase awareness of WUS and increase visits to the screening program for early detection of cervical cancer using the IVA examination method.
\end{abstract}

Keywords: Health Belief Model,IVA, Cervical Cancer, WUS

\section{PENDAHULUAN}

Kanker yang menyebabkan kasus kematian perempuan tertinggi di dunia yaitu kanker payudara dan kanker leher rahim . Data World Health Organization (WHO) menyatakan sekitar 500.000 perempuan di 
dunia terdiagnosa kanker leher rahim dan lebih dari 250.000 meninggal setiap tahunnya. Kanker leher rahim merupakan keganasan yang terjalin pada leher rahim merupakan bagian terendah dari rahim yang menonjol ke puncak liang vagina. Deteksi dini kanker leher rahim dapat dilakukan dengan skrining, skrining pemeriksaan Inspeksi Visual Asam Asetat (IVA) serta pap smear . Namun dalam program pemerintah menggunakan skrining IVA gratis dalam setiap tahunnya terjadwal rutin dilakukan di semua PUSKESMAS yang tersebar di Indonesia.

Data Profil Dinas Jawa Barat Tahun 2019 Kabupaten Ciamis terdapat 0,2\% cakupan IVA positif dari 1282 peserta positif, 20 peserta pemeriksaan IVA atau $1,5 \%$ dari sekabupaten Ciamis. Dari data tersebut terlihat sangat rendah peminat pemeriksaan IVA oleh perempuan 30-50 tahun di Kecamatan Baregbeg Kabupaten Ciamis. Pada tahun 2020 Kecamatan Baregbeg menduduki wilayah no pertama peserta IVA yang paling rendah peserta pemeriksaan IVA dibandingkan dengan yang kecamatan di Ciamis lainnya, yaitu 25 peserta. Pada 5 tahun terakhir terdapat 3 kasus di PUSKESMAS Baregbeg positif kanker leher rahim stadium lanjut.

Usaha penanggulangan antisipasi benar dipengaruhi dengan persepsi kepercayaan kesehatan atau penilaian terhadap kepercayaan kesehatan/ health belief model. Kepercayaan dan presepsi individu terhadap sesuatu akan menanamkan agenda tindakan tentang diri individu tersebut. Teori Health Belief Model biasa digunakan dalam menerangkan perubahan terhadap perilaku kesehatan dimasyarakat. Teori ini menekankan aspek kepercayaan dan presepsi individu. Konsep kepercayaan kesehatan dipelopori oleh Rossenstock pada tahun 1974 dan berkembang sampai tahun 2005 oleh Cooner. Health Belief Model ialah faktor yang dapat mempengaruhi keputusan untuk bertindak melakukan kegiatan kesehatan. Terdapat beberapa bagian dari Health Belief Model, yaitu kerentanan yang dirasakan (perceived susceptibility), keparahan yang dirasakan (perceived severity), ancaman yang dirasakan (perceived threat), manfaat yang dirasakan (perceived benefit), hambatan yang dirasakan (perceived barrier), dan isyarat bertindak (cues to action).
Studi pendahuluan penelitian didapatkan masih rendahnya minat Wanita Usia Subur di wilayah kerja PUSKESMAS Baregbeg terhadap deteksi dini kanker leher rahim dengan metode pemeriksaan IVA, pada tahun 2020 terdapat $0,25 \%$ pemeriksa IVA walaupun naik $0,5 \%$ peserta dari tahun 2019 terdapat $0,2 \%$ peserta tetapi masih jauh dengan yang diharapakan yaitu $80 \%$ dari WUS yang ada di wilayah (Data dari hasil wawancara peneliti dengan Bidan PUSKESMAS Baregbeg). Peneliti melakukan wawancara dengan sepuluh WUS di wilayah kerja PUSKESMAS Baregbeg didapatkan hasil kepercayaan kepercayaan kesehatan deteksi dini kanker leher rahim menggunakan metode pemeriksaan IVA rendah. Sebanyak enam WUS tidak pernah melakukan deteksi dini menggunakan metode pemeriksaan IVA, sebanyak sembilan WUS mengatakan dirinya tidak rentan terhadap penyakit kanker leher rahim yang berarti perceived susceptibility rendah, sepuluh WUS mengatakan manfaat yang didapatkan sangat baik tetapi tidak berdampak besar karena mereka sudah menduganya terlebih dahulu artinya perceived benefitnya baik, enam WUS mengatakan tidak melakukan pemeriksaan dikarenakan takut berarti perceived barrier baik, dari tujuh WUS mengatakan tidak mengetahui adanya pemeriksaan IVA gratis setiap tahunnya di PUSKESMAS Baregbeg artinya cues to action rendah. Berdasarkan kejadian tersebut peneliti ingin meneliti tentang Gambaran Kepercayan Kesehatan WUS Dalam Deteksi Dini Kanker Leher Rahim Menggunakan Metode Pemeriksaan IVA (Inpseksi Visual Asam Asetat) di Wilayah Kerja PUSKESMAS Baregbeg Tahun 2021.

\section{METODE PENELITIAN}

Tempat penelitian ini dilakukan di wilayah kerja PUSKESMAS Baregbeg, pada 3 Mei 2021-22 Juni 2021. Teknik pengambilan sampel yang digunakan dalam penelitian ini adalah non probability sampling/ non random sampling, yaitu penarikan sampel tidak acak . Jenis pengambilan sampel non probality pada penelitian ini menggunakan consecutive sampling. Consecutive sampling yaitu pengambilan sampel dengan mengambil setiap responden yang masuk kriteria inklusi pada kurun waktu tertentu Populasi penelitian ini yaitu wanita usia subur usia 15 sampai 49 
tahun yang telah menikah dan bertempat tinggal di wilayah kerja PUSKESMAS Baregbeg sejumlah 647 orang Populasi penelitian berjumlah sebanyak 647 WUS.
Jadi sampel $19,35 \%$ dari populasi yaitu $19,35 \%$ x $647=125,1945$ dibulatkan menjadi 126. Jadi sampel yang akan digunakan pada penelitian ini sebesar 126 WUS.

\section{HASIL PENELITIAN DAN PEMBAHASAN \\ Hasil Penelitian}

Berdasarkan hasil peneilitian di wilayah kerja PUSKESMAS Baregbeg dapat gambarkan sebagai berikut:

Tabel 1

Gambaran Health Belief Model WUS dalam Deteksi

Dini Kanker Leher Rahim Menggunakan Metode

\begin{tabular}{|c|c|c|c|c|c|c|}
\hline \multirow[b]{2}{*}{ Komponen } & \multirow[b]{2}{*}{$\begin{array}{l}\text { Baik } \\
(\%)\end{array}$} & & \multirow[b]{2}{*}{ Max } & \multirow[b]{2}{*}{ Min } & \multirow[b]{2}{*}{ Kategori } \\
\hline & & $\begin{array}{l}\text { Kurang } \\
(\%)\end{array}$ & Mean & & & \\
\hline $\begin{array}{l}\text { Health Belief } \\
\text { Model (Total) }\end{array}$ & $\begin{array}{l}46 \\
(36,5 \%)\end{array}$ & $\begin{array}{l}80 \\
(63,5 \%)\end{array}$ & 126,3 & 175 & 91 & Kurang \\
\hline $\begin{array}{l}\text { Perceived } \\
\text { Susceptibility }\end{array}$ & $\begin{array}{l}56 \\
(44,4)\end{array}$ & $\begin{array}{l}70 \\
(54,6 \%)\end{array}$ & 30,4 & 67 & 19 & Kurang \\
\hline $\begin{array}{l}\text { Perceived } \\
\text { Severity }\end{array}$ & $\begin{array}{l}58 \\
(46 \%)\end{array}$ & $\begin{array}{l}68 \\
(54 \%)\end{array}$ & 11,3 & 16 & 6 & Kurang \\
\hline $\begin{array}{l}\text { Perceived } \\
\text { Benefit }\end{array}$ & $\begin{array}{l}85 \\
(67,5 \%)\end{array}$ & $\begin{array}{l}41 \\
(32,5 \%)\end{array}$ & 9,8 & 14 & 6 & Baik \\
\hline $\begin{array}{l}\text { Perceived } \\
\text { Barrier }\end{array}$ & $\begin{array}{l}53 \\
(42,1 \%)\end{array}$ & $\begin{array}{l}73 \\
(67,9 \%)\end{array}$ & 43,5 & 80 & 29 & Kurang \\
\hline $\begin{array}{l}\text { Cues } \\
\text { Action }\end{array}$ & $\begin{array}{l}57 \\
(45,2 \%)\end{array}$ & $\begin{array}{l}69 \\
(54,8 \%)\end{array}$ & 31,4 & 38 & 20 & Kurang \\
\hline
\end{tabular}

Hasil penelitian menyatakan bahwa health belief model WUS dalam deteksi dini kanker leher rahim menggunakan metode pemeriksaan IVA hampir setengah dari jumlah responden health belief baik sebanyak 46 WUS (36,5\%), dan sebagian besar responden belief kurang sebanyak 80 WUS $(63,5 \%)$. Maka dapat disimpulkan gambaran health belief model WUS dalam deteksi dini kanker leher rahim menggunkaan metode pemeriksaan sebagian besar kurang. Dimana jika dilihat dari per item komponen yang ada didalam health belief model komponen yang nilainya paling kurang ialah hambatan yang dirasakan (perceived barrier) dan paling nilai yang baik adalah manfaat yang dirasakan (perceived benefit).

\section{Pembahasan}

Hasil penelitian menggambarkan bahwa sebagian besar dari jumlah responden atau WUS yang memiliki health belief kurang dalam deteksi dini kanker leher rahim menggunakan metode pemeriksaan IVA. Hal ini berbanding lurus terhadap target PUSKESMAS baregbeg untuk program test IVA yang hanya $0,25 \%$ dari target total $80 \%$

WUS di wilayah kerja PUSKESMAS. Hasil penelitian menunjukkan bahwa kurangnya health belief model WUS dalam deteksi dini kanker leher rahim. Health Belief Model dapat dipengaruhi oleh beberapa faktor yaitu data kependudukan, status repoduksi, dan keyakinan penyebab kanker leher rahim serta kesedian melakukan upaya pencegahan kanker leher rahim, contoh vaksin HPV.

Pendidikan responden sebagian besar 70 WUS (55,56\%) ialah SMP/SLTP, sehingga tingkat pendidikan responden dianggap kurang (karena program pendidikan di Indonesia minimal 12 tahun). Nursalam (2010) menyatakan bahwa semakin tinggi pendidikan seseorang semakin mudah menentukan informasi sehingga semakin banyak pula pengetahuan yang dimilikinya begitu sebailknya pendidikan yang kurang akan menghambat perkembangan sikap seseorang terhadap nilai baru yang diperkenalkan. Pendidikan mempunyai peran positif terhadap masalah kesehatan, sehingga secara tidak langsung berdampak pada perilaku kesehatan. Data pekerjaan responden sebagian besar 95 WUS $(75,4 \%)$ sebagai ibu rumah tangga. WUS sebagai ibu 
rumah tanga memiliki waktu luang yang sangat banyak dan memiliki waktu yang lebih untuk melakukan pemerikasaan IVA di PUSKESMAS. Namun penelitian sbelumnya didapatkan bahwa WUS sebagai ibu rumah tangga tidak memiliki waktu untuk melakukan pemeriksaan IVA dengan berbagai alasan salah satunya hambatan yang dirasakan (perceived barrier) tinggi (63\%) dibandingkan dengan komponen health belief model yang lainnya (Sutrisni, 2016).

Status repoduksi dapat meningkatkan health belief WUS karena status repoduksi responden yang baik akan meningkatkan kerentanan, keparahan, manfaat, hambatan dan alasan ingin melakukan test IVA. Kunjungan test IVA di wilayah kerja PUSKESMAS masih jauh dari target, sehingga dapat disimpulkan jarang sekali WUS yang pernah melakukan test IVA. Dari 126 responden penelitian hanya ada 3 responden yang pernah melakukan test IVA. Dan yang terakhir keyakinan kesehatan mengenai penyebab kanker leher rahim dan kesedian vaksin HPV dapat mempengaruhi health belief WUS karena WUS yang mempunyai pengetahuan mengenai penyebab kanker leher rahim yang baik akan mencegah dirinya untuk meningkatkan rentan dengan resiko penyakit. WUS dengan kesedian melakukan vaksin menunjukkan bahwa kesadaran akan upaya pencegahan kanker leher rahim baik. Dari 126 responden sendiri hanya sebagian kecil sebanyak 20 WUS (16\%) yang mau melakukan vaksin HPV. Hal ini dapat meningkatkan health belief WUS dalam deteksi dini kanker leher rahim. Komponen health belief model menggambarkan bahwa hampir seluruh komponen health belief model memiliki hasil sebagian besar kurang, tetapi yang paling kurang hasilnya adalah hambatan yang dirasakan (perceived barrier). Hambatan terbesar responden dalam melakukan pemeriksaan IVA yaitu di P 24 dan P 26 dimana responden menjawab tidak setuju dan sangat tidak setuju sebanyak 75 responden atau sebesar 59\% dari 126 responden.

Hal ini sesuai dengan penelitian sebelumnya. Pada penelitian sebelumnya di Amerika Latin tahun 2011 mengatakan bahwa beberapa hambatan yang paling banyak dilalui WUS ketika akan melakukan pemeriksaan IVA ialah kecemasan hasil dari test IVA, responden tidak meliki banyak waktu, bentrok waktu saat akan melakukan test IVA bahkan tidak tahu ada jadwal test
IVA yang diselenggarakan. Responden juga memiliki hambatan yaitu kurangnya pengetahuan tentang test IVA, dari hasil penelitian terdapat bahwa WUS tidak tahu kapan dan pada usia berapa ia harus test IVA sebagai deteksi dini kanker leher rahim. Penataklasanaan dari hasil penelitian tersebut untuk yang health belief kurang dapat dapat dengan dilakukannya penyuluhan rutin pada setiap daerah tentang deteksi dini kanker leher rahim, serta tidak melakukan pemeriksaan IVA secara masal selalu di PUSKESMAS, dapat dilakukan dengan bergantian setiap daerah desa. Selain itu juga memberikan motivasi untuk WUS melakukan pemeriksaan IVA, memperbanyak penyuluhan melalui social media, memasang banner tentang pemeriksaan IVA ataupun kanker leher rahim.

\section{SIMPULAN}

Health belief model WUS dalam deteksi dini kanker leher rahim menggunakan metode pemeriksaan IVA hampir setengah dari jumlah responden yang baik sebanyak 46 WUS (36,5\%), dan sebagian besar dari jumlah responden yang kurang sebanyak 80 WUS $(63,5 \%)$.

\section{DAFTAR PUSTAKA}

Dinas Kesehatan Jawa Barat. (2019). Profil Kesehatan Jawa Barat. bandung

Puskesmas Baregbeg. (2020). Profil Kesehatan PUSKESMAS Baregbeg. Ciamis 